\title{
Sprawozdanie
}

\section{Seminarium Młodych Badaczy Prawa Konstytucyjnego nt.: Systemy rządów w państwach europejskich, Gdynia, 5-7 października 2010 r.}

Zgodnie z zapowiedziami i ustaleniami powziętymi podczas I Seminarium Młodych Badaczy Prawa Konstytucyjnego, które - przypomnijmy - miało miejsce 11-12 marca 2010 r. w Mąchocicach Kapitulnych, w dniach 5-7 października 2010 r. w Gdyni odbyło się kolejne z tego cyklu II Seminarium Młodych Badaczy Prawa Konstytucyjnego. Gospodarzami II edycji Seminarium byli Koleżanki i Koledzy z Katedry Prawa Konstytucyjnego i Instytucji Politycznych Uniwersytetu Gdańskiego, których pomysłowość i inicjatywa doprowadziły do zorganizowania obrad oraz zakwaterowania uczestników na żaglowcu szkoleniowym Akademii Morskiej w Gdyni - „Darze Młodzieży”, zacumowanym przy kei Skweru Kościuszki w Gdyni. W tym nietypowym jak na spotkania naukowe miejscu przebiegały obrady prawników oraz politologów, reprezentujących młodych badaczy prawa konstytucyjnego, z większości ośrodków uniwersyteckich w Polsce.

Warto zaznaczyć w tym miejscu, że od czasu I Seminarium aktywność naukowa młodych badaczy zyskała wymierny efekt publikacyjny w postaci wydania pierwszego numeru kwartalnika „Przegląd Prawa Konstytucyjnego", którego zawartość merytoryczna była przedmiotem oceny oraz wielu dyskusji uczestników II Seminarium. Jednocześnie powstała strona internetowa http://www.seminariummlodych.cba.pl, na której zamieszczane są bieżące informacje na temat kolejnych planowanych Seminariów Młodych Badaczy Prawa Konstytucyjnego oraz ich tematach, co pozwala na dotarcie tą drogą do szerokiego kręgu osób zainteresowanych określoną problematyką.

Problematyka seminarium - zgodnie z wcześniejszymi ustaleniami była skoncentrowana wokół tematu: „Systemy rządów w państwach europej- 
skich". Obrady zostały podzielone na trzy sesje, z czego dwie odbyły się 6 października, a trzecia 7 października. II Seminarium Młodych Badaczy Prawa Konstytucyjnego otworzył przedstawiciel gospodarzy dr M. M. Wiszowaty (Uniwersytet Gdański), który w swoim inauguracyjnym wystąpieniu zwrócił uwagę na cykliczność spotkań stabilizującego się grona młodych badaczy uczestniczących w seminariach oraz nakreślił plany na najbliższe spotkania organizowane w 2011 r. przez pracowników Katedr Prawa Konstytucyjnego Uniwersytetu Warmińsko-Mazurskiego i Uniwersytetu Łódzkiego.

Pierwszej, przedpołudniowej sesji 6 października 2010 r. przewodniczył dr J. Rychlik (Szkoła Wyższa Psychologii Społecznej w Warszawie). Jako pierwsza referat na temat Kontrasygnata jako wyznacznik systemu rzadów przedstawiła dr A. Frankiewicz (Uniwersytet Opolski). Referentka przeanalizowała w swoim wystąpieniu systemy rządów, w kontekście występowania instytucji kontrasygnaty aktów urzędowych głowy państwa, zwracając szczególną uwagę na występujące w tej materii odrębności w poszczególnych krajach.

Następnie głos zabrała dr M. Florczak-Wątor (Uniwersytet Jagielloński), która przedstawiła referat Zastępstwo głowy państwa w RP na tle rozwiązań $w$ wybranych krajach europejskich. Autorka dokonała analizy instytucji zastępstwa głowy państwa, przesłanek skutkujących zastępstwem oraz możliwych sytuacji, w której głowa państwa nie może wykonywać swojego urzędu. Szczególne zainteresowanie słuchaczy wywołała teza, iż katalog przesłanek opróżnienia urzędu zawarty w art. 131 ust. 2 Konstytucji Rzeczypospolitej Polskiej ma tylko pozornie charakter katalogu zamkniętego, bowiem jedna z przesłanek wskazanych w pkt. 3 przywołanego artykułu (,innych przyczyn nieobjęcia urzędu po wyborze" ) otwiera ten katalog.

Ostatni referat w tej sesji wygłosił dr M. Dąbrowski (Uniwersytet Warmińsko-Mazurski), przestawiając problematykę ograniczonej zdolności do czynności prawnych jako przesłanki utraty praw wyborczych w świetle standardów europejskich. Autor podzielił się wątpliwościami jakie wiążą się z przesłankami utraty prawa wyborczego, zwłaszcza wobec osób o ograniczonej zdolności do czynności prawnych, wskazując na zaniechanie badania tej kwestii przez sądy powszechne w postępowaniach o ubezwłasnowolnienie częściowe.

I sesja zakończyła się burzliwą dyskusją, w którą zaangażowani byli niemal wszyscy uczestnicy seminarium. Szczególnym zainteresowaniem, które zna- 
lazło wyraz w pytaniach kierowanych do referentów oraz przedstawieniem własnych wątpliwości i przemyśleń uczestników seminarium, cieszyły się zagadnienia związane z praktycznym aspektem zastępstwa głowy państwa. Uczestnicy seminarium krytycznie ocenili przyjęte przez polskiego ustrojodawacę regulacje art. 131 Konstytucji Rzeczypospolitej Polskiej. Miało to związek z niedawnymi problemami zaistniałymi w tej materii w kontekście katastrofy smoleńskiej.

Przewodnictwo II popołudniowej sesji objął dr P. Uziębło (Uniwersytet Gdański). Jako pierwszy głos zabrał dr K. Krysieniel (Wyższa Szkoła Bankowa w Poznaniu Wydział Zamiejscowy w Chorzowie), który przedstawił problematykę Ewolucji systemu politycznego w Chorwacji w latach 1990-2010. Referent zaprezentował przebieg zmian systemu politycznego Chorwacji, od nacjonalistycznych rządów F. Tudjmana po proces demokratyzacji sceny politycznej, zapoczątkowany wyborami w $2000 \mathrm{r}$.

Kolejny referat, zatytułowany Parlament Chorwacji $w$ systemie podziału władz wygłosił dr K. Składowski (Uniwersytet Łódzki). Rozwiązania w przedmiocie chorwackiego parlamentaryzmu autor przedstawił w dwóch zakresach czasowych, od uchwalenia konstytucji w 1995 r. do 2001 r. i po przyjęciu poprawki do konstytucji w 2001 r. Do 2001 r. parlament chorwacki był dwuizbowy, składał się z Izby Przedstawicielskiej i Izby Żupanyj. Autor szczególną uwagę zwrócił na genezę wprowadzenia dwuizbowości w Chorwacji, skład i kompetencję Izbę Żupanyj, a także przyczyny odejścia od dwuizbowości na rzecz jednoizbowego parlamentu - Zgromadzenia Chorwackiego.

Wystąpienie dr. K. Urbaniaka (Uniwersytet Warszawski) poświęcone było cechom brytyjskiego systemu rządów. Wskazując na klasyczne cechy systemu parlamentarno-gabinetowego, autor odniósł do praktyki brytyjskiego systemu rządów, opartego na zwyczaju i konwenansie konstytucyjnym.

Jako ostania w tym dniu głos zabrała dr M. Lorencka (Uniwersytet Śląski). W swoim referacie przedstawiła Dyskusje wokół formy rządów we Włoszech w ostatnich trzydziestu latach. Autorka skupiła się na omówieniu poglądów przedstawicieli środowisk politycznych na kwestie włoskiego modelu rządów, poszukiwaniu nowych rozwiązań oraz propozycji zmian w strukturze organów władzy, jakie można było zaobserwować na przestrzeni ostatnich kilkudziesięciu lat, zwłaszcza w kontekście niekonwencjonalnych poczynań premiera Silvio Berlusconiego. 
III sesji, która odbyła się w dniu 7 października, przewodniczył dr P. Czarny (Uniwersytet Jagielloński). Jako pierwsza referat przedstawiła dr A. Bień-Kacała (Uniwersytet Mikołaja Kopernika) na temat skrócenia kadencji parlamentu w Polsce i Republice Czeskiej. Przyjmując za punkt wyjścia przyjęte w Rzeczypospolitej Polskiej i Republice Czeskiej rozwiązania dotyczące skrócenia kadencji, autorka poszukiwała optymalnego modelu przerywania pełnomocnictw organów przedstawicielskich.

Następnie głos zabrał dr J. Zaleśny (Uniwersytet Warszawski), który przedstawił problematykę inicjatywy ustawodawczej Rządu Federacji Rosyjskiej. Autor skupił się na wskazaniu podmiotów wyposażonych w prawo zgłaszania projektów ustaw, cechach inicjatywy oraz praktycznych aspektach związanych z przygotowywaniem i wnoszeniem projektów przez rząd Federacji Rosyjskiej, wskazując na specyfikę funkcjonowania tego organu w realiach federacji.

Wobec nieoczekiwanego wyjazdu kolejnego zapowiedzianego referenta nie został wygłoszony, ujęty w programie seminarium, referat dotyczący problematyki Systemu sprawowania rządów w Federacji Rosyjskiej. Mimo tego prowadzona po przedstawieniu pozostałych referatów dyskusja, którą dynamicznie inicjował i ochoczo inspirował własnymi przemyśleniami, czuwający nad przebiegiem sesji dr P. Czarny, bez wątpienia objęła również i tą problematykę, która, jak się okazało, jest uczestnikom seminarium świetnie znana. Godna podziwu i pozazdroszczenia aktywność przewodniczącego III sesji stanowiła klasyczny przykład wywoływania dyskusji na temat, który z nieoczekiwanych przyczyn nie został przedstawiony w formie referatu.

Niewątpliwie założenie II Seminarium Młodych Badaczy Prawa Konstytucyjnego, stanowiącego kontynuację zainicjowanego w tym roku pierwszego spotkania naukowego prowadzonego $\mathrm{w}$ tej formule, zostało w pełni zrealizowane. Atmosfera naukowa obrad sprzyjała zarówno poznaniu, jak i przybliżeniu problematyki badawczej realizowanej przez przedstawicieli różnych ośrodków akademickich w Polsce. Toczona w ramach obrad dyskusja inspirująco wpłynęła na uczestników, zachęcając do podejmowania oraz kontynuacji badań, których założenia i tezy były przedstawiane podczas obrad. Dodatkowo to, jak i poprzednie seminarium, okazało się również wspaniałą platformą wymiany doświadczeń związanych z dydaktycznym aspektem pracy prowadzonej na uczelniach przez młodych badaczy. Dyskusje na tej niwie pozwoliły zapoznać się z modelami kształcenia studentów 
funkcjonującymi w poszczególnych ośrodkach dydaktycznych, organizacji pracy wydziałów i katedr oraz wymaganiami stawianymi przed studentami w ramach poszczególnych przedmiotów akademickich wykładanych przez konstytucjonalistów.

Niepowtarzalny, miły i serdeczny nastrój seminarium, wynikający także z miejsca, w którym się ono odbywało oraz osób biorących w nim udział, atmosfera obrad, a także ich wysoki merytoryczny poziom spowodowały, że spotkanie zorganizowane w ramach II Seminarium na długo pozostanie w pamięci uczestników i jako takie będzie dobrze wspominane. Kontynuacja tych spotkań rysuje się jako nieodzowna potrzeba środowiska naukowego młodych badaczy, która już w niedługim czasie zostanie zrealizowana przez Koleżanki i Kolegów z Uniwersytetu Warmińsko-Mazurskiego, na co pozostaje z niecierpliwością oczekiwać.

Joanna Juchniewicz (Uniwersytet Warmińsko-Mazurski w Olsztynie) Przemysław Mijal (Uniwersytet Szczeciński) 